\title{
The Effect of Bioremediated Diesel Polluted Soil Ammended with Eicchorniacrassipes (Water Hyacinth) on the Germination Parameters of AmaranthushybridusL. (Green Amaranth)
}

\author{
M. I. Saheed ${ }^{1}$, A. Foluke ${ }^{2}$, K. L. Njoku ${ }^{3}$, C. C. Ndiribe ${ }^{4}$ \\ ${ }^{1,2,34}$ Department of Cell Biology and Genetics, University of Lagos, Akoka Lagos, Lagos
}

\begin{abstract}
The aim of this research is to investigate the effects of bioremediated soil using Echhoniacrassipes(water hyacinth) on the germination parameters such as days to germination of Amarathushybridus(green amaranth) and the physico-chemical profile such as total petroleum hydrocarbon (TPH) of the bioremediated soil with water hyacinth. $1 \mathrm{~kg}$ of soil was polluted with $700 \mathrm{ml}$ of diesel oil in perforated plastic containers size $(64 \times 21 \mathrm{~cm})$ and amended withE.crassipes (water hyacinth) at 50,100 and 150g concentrations for 90 days. About 5 seeds of A.hybriduswere sown on the bioremediated soil for 50 days. Positive (1 kg of unpolluted soil) and negative (1 kg of $700 \mathrm{ml}$ diesel oil polluted soil) controls were used.It was observed thatA. hybridus seeds in the positive control had the quickest day to germination (7 days). An average of 12, 11, and 9 days to germination was observed in soil treated with E.crassipes at 50, 100 and 150 concentrations respectively. For the negative control, day to germination was late (20days). A significant difference was obtained in the root length and plant height and percentage germination between the positive and negativecontrol. However, there was no significant difference between the positive control and the soil treated with E. crassipes at the three concentrations. The study had shown that diesel contamination affected germination and growth of A. hybridusplant adversely. However, E.crassipescan be effectively used to reduce the adverse effect of diesel polluted soil on A.hybridusand therefore serve as bioremeditor of diesel oil polluted soil.
\end{abstract}

Keywords: Bioremediation, Echhoniacrassipes(water hyacinth), Amarathushybridus(green amaranth), Positive control, Negative control, Total petroleum hydrocarbon, Diesel oil.

\section{Introduction}

Since commercial exploration of petroleum started in Nigeria in 1958 Okoh [1], petroleum has continuously grown to be mainstay of the Nigerian economy. However, the exploration and transportation of petroleum and its products such as diesel oil has led to the pollution of agricultural lands and water ways Njokuet al. [2]. Several civil unrests due to environmental degradation due petroleum exploration have also been witnessed in Nigeria Inoniet al. [3]. Therefore, the urgent need of clean-up of petroleum polluted sites becomes paramount.

Bioremediationis the use of either naturally occurring organisms or deliberately introduced micro-organisms to consume and break down environmental pollutants, in order to clean up a polluted site Azubuikeet al. [4]. It is a process wherein soil organisms reduce contaminant concentration through degradation, detoxification, stabilization, or transformation Azubuikeet al. [4]. It is commonly implemented both in situ such as natural attenuation and ex situ such as composting. The principle of this technique is to optimize soil parameters that govern the rate of biodegradation such as, soil temperature, moisture, porosity, $\mathrm{pH}$, available nutrients and microbial populations. Generally, bioremediation requires less resource input in diesel oil polluted soil than other techniques, and it is perceived as an environmentally friendly approach. However, bioremediation is often slow and unreliable, and thresholds of toxicity to micro-organisms may preclude its use in some circumstances Lim et al. [5].
Diesel oilis a petroleum distillate fuel used in compressionignition engines. It is one of the major products of crude oil and it constitutes a major source of pollution to the environment Nwaoguet al. [6]. The increasing use of diesel oil in engines of cars, industrial trucks and generators has led to an increased demand for itOgbo [7] which causes accidental spillage and pollution of agricultural lands leading to reduced plant growth, soil fertility and microflora population. Diesel oil can enter into the environment through leakage from storage containers and refueling of vehicles. It has been reported to be phytotoxic at relatively low concentrations, contaminates the soil caused a reduction in germination and length of the radicles of Arachis hypogea, Vignaunguiculata, Sorghum bicolor and Zea maysOgbo [7].

Germination is the budding of a seed after it has been planted in soil and remained dormant for a certain period. These seeds eventually grows into young plants through the process of seed germination Tomei et al. [8].

A.hybridus is an erect annual plant with a stem that can be much branched to nearly free branches, it usually grows 30 $200 \mathrm{~cm}$ tall, occasionally to $250 \mathrm{~cm}$. The plant has a history of cultivation as a food crop and is still sometimes cultivated on a small scale for its edible leaves and seeds Aboribo [9]. No member of this genus are known to be poisonous, but can bioaccumulate nitrogen when grown on nitrogen rich soils and may cause stomach cancer, blue babies and some other health problems.

This study is significant because most of the time, we believed a diesel polluted soil has been bioremediated based 


\section{International Journal of Science and Research (IJSR) \\ ISSN (Online): 2319-7064}

Index Copernicus Value (2016): 79.57 | Impact Factor (2015): 6.391

on the physico-chemical profile of the bioremediated soil, butwe never care to check the germination, growth parameters and viability of the crops produced from such soils. Therefore this research aimed at checking the germination parameters of $A$. hybridus produced from $E$. crassipes remediated diesel oil polluted soil.

\section{Materials and methods}

This study was carried out in the Biological garden of the University of Lagos, Akoka Lagos, Nigeria. Seeds of $A$. hybriduswere obtained from an agro allied shop in Bariga, Lagos State. Bioremediated soil with E. crassipes and control soil were obtained from a greenhouse experimental soil in the Biological garden of the University.

$1 \mathrm{~kg}$ of soil was polluted with $700 \mathrm{ml}$ of diesel oil and remediated with $E$. crassipes at different concentrations $(50,100$ and $150 \mathrm{~g})$ for 90 days. 5 seeds of A. hybridus were sown on the remediated soil, positive control soil and negative control soil for 50 days. The positive control soil was made up of $1 \mathrm{~kg}$ of unpolluted soil, while the negative control was made up of $1 \mathrm{~kg}$ of polluted soil with no remediation according to Wyszkowskiet al. [10]. The set up was monitored for the following parameters; Days to germination, percentage germination (\%), root length $(\mathrm{cm})$ and plant height $(\mathrm{cm})$. Days to germination was determined by observing the number of days for first germination, percentage germination was by counting the number of germinated seeds and dividing it by total seeds sown, multiplied by one hundred, root length and plant height was by using a transparent meter rule $(\mathrm{cm})$. Total petroleum hydrocarbon residue (TPH) in the germinated plant was also obtained using gaschromatography and mass spectrophotometer (GC-MS) technique following Eckerts and Sims [11].

The effect of bioremediated soil using E. crassipes on the days to germination, percentage germination, root length and plant height of $A$. hybridus was determined by comparing all the data obtained. Statistical analyses of the data obtained were done using Statistical Package for Social Science (10.0) computer program using a 2 way ANOVA with significance levels at $p=0.05$.

\section{Results and Discussion}

The results indicated a significant difference in Total Petroleum Hydrocarbon residue (TPH) between the positive control and negative control at $p>0.05$. There was no TPH in the positive control compared to $50 \mathrm{mg} / \mathrm{kg}$ in the negative control. However, there was no significant difference in (TPH) between bioremediated soil with 50, 100 and $150 \mathrm{~g}$ of E. crassipes and the Positive control at $p<0.05$. This might be due to the ability of E. crassipes to breakdown petroleum hydrocarbon in the diesel polluted soil. This is similar to the findings of Siddiqui and Adams [12] who observed a less TPH in petrol polluted soil remediated with E. crassipes.

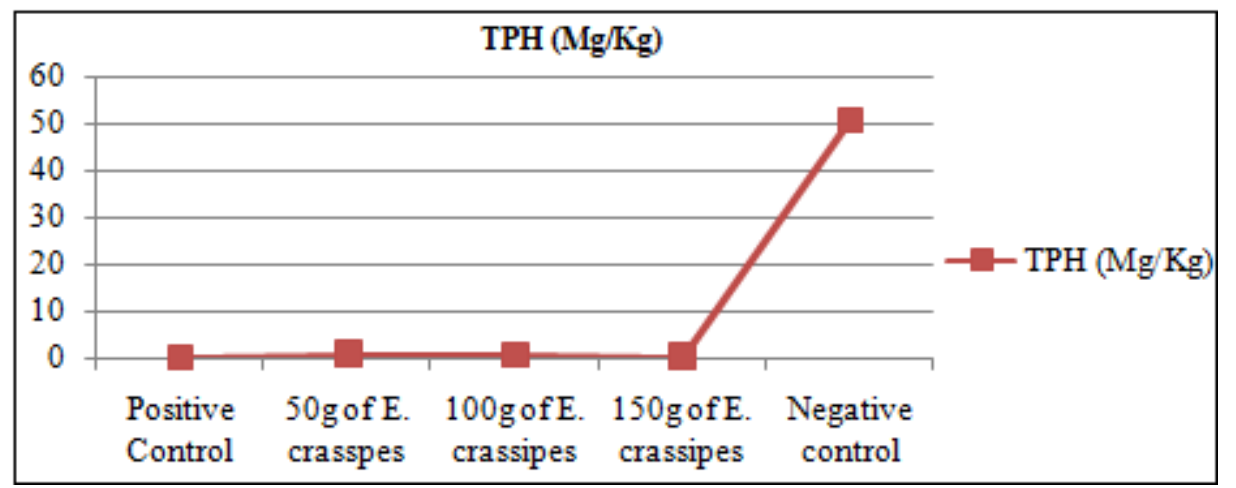

Figure 1: Total Petroleum Hydrocarbon residue in A. hybridus at three different concentrations after 50 days (Seven weeks)

The study indicated a significant delay in days to germination between the positive and negative control. The positive control germinated in 7 days, while the negative control took up to 20 days. This may be due to the prevention of proper functioning of microbes as a result of the inhibition of aeration by high concentration of diesel oil. This is similar to a research made by Kapulnik [13]. Amakiri and Onofeghara [14], reported that oil acts as potent on contact herbicides on seeds forming a film on the seed. However, there was no significant difference in days to germination between the positive control and the bioremediated soil with $E$. crassipes at the three concentrations. Though a more similar results was obtained between positive control and the $150 \mathrm{~g}$ of E. crassipes. A less percentage germination was obtained in the negative control while higher percentage germination was obtained in the positive control and the bioremediated soil. For the root length and plant height,the results indicateda significant difference between the positive and negative control at $p<0.05$. However, there is no significant difference at days to germination, percentage germination, root length and plant height between the positive control and the bioremediated soil with E. crassipes at the three concentrations. This might be due tothe effectiveness of $E$. crassipes in decomposing hydrocarbon polluted soil. 


\section{International Journal of Science and Research (IJSR) \\ ISSN (Online): 2319-7064 \\ Index Copernicus Value (2016): 79.57 | Impact Factor (2015): 6.391}

Table 2: Germination parameters of A. hybridus grown with polluted (Negative control), unpolluted (Positive control) and bioremediated soil at three different concentrations of E. crassipes, after 50 days (Seven weeks).

\begin{tabular}{|c|c|c|c|c|}
\hline Sample & Days to germination & \% Germination & Plant height $(\mathrm{cm})$ & Root length $(\mathrm{cm})$ \\
\hline Positive Control & 7 & $80 \pm 0.33$ & $25 \pm 0.49$ & $6.9 \pm 0.50$ \\
\hline NegativeControl & 20 & $20 \pm 0.33$ & $8 \pm 0.25$ & $1.21 \pm 0.79$ \\
\hline 50g of E.crassipes & 12 & $74 \pm 1.45$ & $23.4 \pm 0.15$ & $6.0 \pm 0.13$ \\
\hline $100 \mathrm{~g}$ of E.crassipes & 11 & $80 \pm 0.00$ & $24.2 \pm 0.15$ & $6.3 \pm 0.12$ \\
\hline $150 \mathrm{~g}$ of E.crassipes & 9 & $80 \pm 1.20$ & $24.9 \pm 0.67$ & $6.6 \pm 0.27$ \\
\hline
\end{tabular}

\section{Conclusion}

The findings of this study indicated that diesel oil polluted soil affects the germination day, percentage germination, root length and height of $A$. hybridus and also led to accumulation of petroleum hydrocarbon in the test plant tissue. However, E. crassipeshas been indicated as effective biostimulant which stimulate the hydrocarbon breakdown on a diesel polluted soil. The E. crassipesled to the breakdown of the hydrocarbon present in the polluted soil and thereby reducing the total petroleum hydrocarbon residue on the soil polluted with diesel oil. Therefore this study suggests the use of higher concentration of both powdered and fresh $E$. crasspies to check its effectiveness in hydrocarbon breakdown. Studies should also be conducted on soil polluted with other hydrocarbons such as kerosene, petrol, engine oil and bitumen to check the effectiveness of $E$. crassipeson hydrocarbon breakdown.

\section{References}

[1] A. Okoh, Biodegradation of Bonny light crude oil in soil microcosm by some bacteria strains isolated from crude oil flow stations saver pits in Nigeria, African Journal of Biotechnology.2 (2003) 104-108.

[2] L. Njoku, O. Akinola, B. Oboh, Germination, survival and growth of accession of Glycine max L. (Merril) (Soybean) and LycopersiconesculentumL. (Tomato) in crude oil polluted soil, Research Journal of Environmental Toxicology.2(2009) 77-84.

[3] O. Inoni, D. Omotor, F. Adun, The effect of oil spillage on crop yield and farm income in Delta State, Nigeria, Journal of Central European Agriculture. 7(2006) 41-49.

[4] C. Azubuike, B. Chikere, C. Okpokwasili, Bioremediation technique classification based on site of application: principles, advantages, limitations and prospects, World Journal of Microbiology and Biotechnology. 32 (2016) 180-186.

[5] W. Lim, E. Von- Lau, E. Poh, A comprehensive guide of remediation technologies for oil contaminated soilpresent works and future directions, Journal of Marine Pollution. 109 (2016) 14-45.

[6] A. Nwaogu, G. Onyeze, R. Nwabueze, Degradation of diesel oil in polluted soil using Bacillus subtilis, African Journal of Biotechnology. 7(2008) 1939-1943.

[7] E. Ogbo, Effect of diesel fuel contamination on seed germination of four crop plants Arachishypogea, Vignaunguiculata, Sorghum bicolor and Zea mays, African Journal of Biotechnology. 8(2009) 250253.

[8] M. Tomei, J. Dauglis, Ex situ bioremediation of contaminated soils: an overview of conventional and innovative technologies, Critical Reviews in
Environmental Science

and

Technology.43

(2013) 21-39.

[9] R. Aboribo, Oil politics and the Niger Delta Development Commission (NDDC). Thetussle for control and domination,African Journal of Environmental Study. 2 (2001) 168-175.

[10] M. Wyszkowski, J. Wyszkowska, S. Zoilkowska, Effect of soil contamination with diesel oil on yellow lupine yield and macroelements contents,Plant Soil Environment Journal.50 (2014) 2 18-226.

[11]D. Eckert, J. Sims, Recommended soil pH and Lime Requirement tests.

http://ag.udel.edu/extension/information/prod_agric/cha p3-95.htm last accessed date. $22^{\text {nd }}$ of October, 2017.

[12] S. Siddiqui, A. Adams, The fate of diesel hydrocarbons in soils and their effect on the germination of perennial ryegrass,Journal of Environmental Toxicology.16 (2002) $49 \quad 62$.

[13] Y. Kapulnik, Y. Waisel, A. Eshel, A. Kaffkafi, D. Mercel, Plant growth promotion by rhizosphere bacterial in plant roots,Journal of Environmental Science. 48 (1996) 769-781.

[14][14]J. Amakiri, F. Onafeghara, Effect of crude oil pollution on the growth of Zea mays, Abelmoschusesculentus and Capsicum fructescens, Journal of Oil Petro-Chemical Pollution.2 (1983) 199205. 